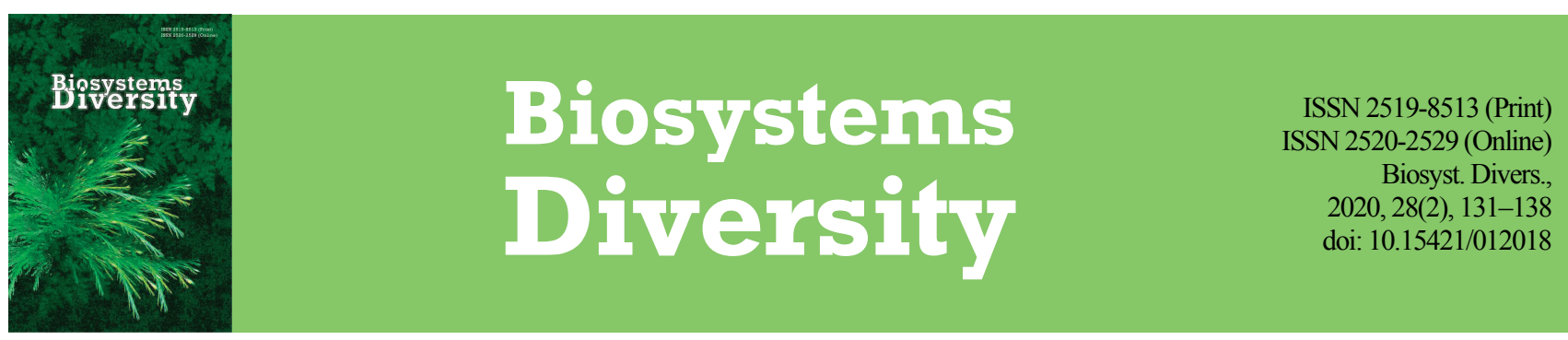

\title{
Radial increment in European spruce (Picea abies) as indicator of sanitary condition of spruce forests in the Ukrainian Carpathians
}

\author{
N. F. Prykhodko*, T. V. Parpan*, M. M. Prykhodko** \\ *Ukrainian Scientific-Research Institute of Mountain Forestry (UkrNDIgirlis) named after P.P. Pasternak, Ivano-Frankivsk, Ukraine \\ **Ivano-Frankivsk National Technical University of Oil and Gas, Ivano-Frankivsk, Ukraine
}

Article info

Received 10.04.2020

Received in revised form 08.05 .2020

Accepted 09.05.2020

Ukrainian Scientific-

Research Institute

of Mountain Forestry

(UkrNDIgirlis) named

after P.P. Pasternak,

Hrushevskogo st., 31

Ivano-Frankivsk,

76000, Ukraine.

Tel.: +38-034-253-02-36

E-mail:girlis@ukr.net

Ivano-Frankivsk

National Technical

University of Oil

and Gas, Karpatska st.

15, Ivano-Frankivsk,

76019, Ukraine.

Tel.: +38-034-254-71-39

E-mail:

admin@mung.edu.ua

As of 2018, the area of desiccation of spruce forests in the region of the Ukrainian Carpathians equaled over 36 thousand ha, and the mass of drying trees was $11 \mathrm{M} \mathrm{m}^{3}$ (Makarenko, 2018). This process has spread to all age groups of the forests. Over recent years, the processes of dessication have spread to spruce forest stands in the Carpathians at the height of over $1,000 \mathrm{~m}$ above the sea level. This process causes significant economic losses, deterioration of the condition and productivity of the Carpathian forests, reduction of the level of ecosystem services by forests, deterioration in performance of their function, thus leading to dangerous exogenous processes (floods, freshets, erosions, mudflows, landslides) (Holubchak et al., 2019; Prykhodko et al., 2019).

Characteristic external signs of the decrease in the vitality of tree stands and statistically reliable changes of taxonomic indicators appear only due to the harmful effect of natural and anthropogenic factors when, most often, the changes in the ecosystems are irreversible. Obviously, more detailed survey methods are needed for the evaluation of the effects. The problem of dehydration and desiccation of forests is impossible to solve based only on studies of separate processes. The studies should be oriented to temporal dynamics of variability of the production process reflected in the growth gain of the trunk mass under the effect of natural and anthropogenic factors. As an indicator which allows assessment of the changes in the forest ecosystems, growth rings are used (Shvedov, 1982; Lovelius \& Grican, 1998; Shijatov et al., 2000; Matjushevskaja, 2017). Radial increment is an objective indicator of the condition of the ecosystem and is not dependent on subjective interpretation of their transformations.

The annual increment of trees is affected by a number of both internal and external factors which take effect in a complex manner. Among the internal factors, the greatest effects are related to the species of the tree (Magnuszewski et al., 2015; Sitková et al., 2018, Burri et al., 2019), inherited individual variability, age and fruiting (Ding et al., 2017; Latreille et al., 2017; Buras et al., 2018). The most influential external factors are latitudinal, longitudinal and height gradients of the conditions of growth locations of the trees (Magnuszewski et al., 2015; Matskovsky, 2016; Chen, 2017; Gao et al., 2018), air temperature and precipitations (Natalini et al., 2015; Rybníček et al., 2016; Rozas \& Olano, 2017), wind (Dinulica et al., 2016), mist (Myskow et al., 2019), soil conditions (Mendivelso et al., 2016), phytocenosis relations (Latreille et al., 2017; Moreau et al., 2019), catastrophes of various origin: fires (Gao et al., 2017), windthrows and windsnaps (Holeska et al., 2016), diseases, attacks of harmful insects (Brygadyrenko, 2016; Faly et al., 2017; Van de Gevel et al., 2017; Wang, 2018), summer and winter droughts, emissions of $\mathrm{CO}_{2}$ (Cavlovic et al., 2015; Svobodova et al., 2019), heavy frosts during snowless periods (Su- 
vanto et al., 2017), and also agricultural activity by humans (Montoro Girona et al., 2016; Tyukavina et al., 2017; Wang et al., 2018). Forest felling, meso- and macro scale effects on the environment lead to negative tendencies of radial increment and deforestation (Rodriguez-Caton, 2015). Radial increment of trees (width of annual ring) is controlled by the external factors and is modified by the external ones (Tishin \& Chizhikova, 2018).

Dendrochronological methods are used to study the history of forest phytocenoses (Moreau, 2019), for recreation of long-term dynamics and cyclicity of climate (Matskovsky, 2016), study of the condition and dynamics of forest ecosystems and reconstruction of the factors of the external environment and long intervals of time with high temporal distribution ability (Holeksa, et al., 2016), determining the mechanisms of the formation of trees in ontogenesis. The data of annual rings of the trees allow identification of earlier unknown events, and are used to study the synchronicity of the changes in the environment in space and time, geomorphological processes (Zhang et al., 2016; Lee et al., 2017; Tishin \& Chizhikova, 2018). Dendrochronological studies in Ukraine were initiated by Shvedov (1892) in the late XIX century. They began to be carried out on a broader scale in the second half of the XX century (Lovelius \& Grican, 1998; Koval', 2006). Not many dendrochronological studies have been conducted in the Ukrainian Carpathians (Koval', 2006).

The objectives of the study were the dynamics of radial increment of European spruce in the hotbeds of desiccation of spruce, interrelation between radial increment and sanitary condition of the forests for further planning of forestry measures.

\section{Materials and methods}

Dendrochronological studies were performed in 2018 in the hotbeds of drying out of spruce in two constant monitoring plots established in the Rachiv district of Zakarpatia Oblast within the framework of budget scientific research topic No 8 "To develop the prognosis of the sanitary condition and suggest complex of measures for using the drying spruce forests of the Carpathians, taking into consideration of ecological, economic and social approaches". The monitoring plots (geographic coordinates -

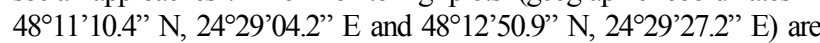
located in the Vysokohirsky forestry district and territory of the Lazeschynskyi Forestry State Enterprise Yasinianske Forest Hunting Range (Table 1). Forest massifs of the enterprise are confined to the slopes of the Chornohora, Svydovetsky range, Pryvododilny Horhan. They are located also in the Yasinianska hollow in the upper reach of the Chorna Tysa River, surrounded by the mountains of average height. In the Vysokohimy forestry district, within the forestry, there are spruce-pine and pure pine forests. Rarely, the main species was European beech (Fagus sylvatica). According to the forest management of 2008, the forest sections of the Lazeschynskyi Forestry, where the surveys were performed, are classified as anti-erosion forests.

The climate in the studied territory is moderate continental humid in the mountain forest belt and moderate-cold above the mountain-forest belt. Average annual air temperature equals $+6.1{ }^{\circ} \mathrm{C}$, maximum $+30.7^{\circ} \mathrm{C}$, minimum $--22.3^{\circ} \mathrm{C}$. Annually, $930 \mathrm{~mm}$ of precipitations falls. The vegetation period lasts for 190 days. Relative air moisture is $82-89 \%$. Soils are unstable. Climatic factors that negatively affect the growth and the development of forests are late spring (1-10 June) and early autumn (21-30 October) ground frosts, often rains, sometimes cloudbursts, strong winds which transform into storms, over the winter period - heavy snowfalls. Notable damage to forestry is caused by windthrows, snowbreaks and windsnaps. The natural damage combined with imperfect methods of the artificial forest renewal in XIX century and mid XX century in particular, "spruce mania" and creation of forests by planting seeds of spruce and firs from the Alps and the Sudetes, have led to significant deterioration of the condition and productivity of the forests of the Ukrainian Carpathians.

Visually the condition of the forest in the monitoring plot No 1 is characterized by insignificant signs of desiccation of spruce, in the second onenotable signs of drying (Fig. 1).

The method of free selection, we chose visually healthy trees of European spruce (up to 9 model trees in each monitoring plot) taking into account the representativeness by trunk thickness gradation, in which, using an increment borer, tree cores were removed at the height of $1.3 \mathrm{~m}$. The width of the annual rings was measured using DIGI-MET micrometer with the accuracy of $0.01 \mathrm{~mm}$. According to the results of the measurements, we determined the annual radial increments for each model tree, developed individual and generalized tree ring chronologies.

To exclude the effect of the age factor on the dynamics of the radial increment, we standardized the data (calculated relative increment indices). The standardization of the data was performed in two stages. At the first stage the "norm of increment" was calculated. To determine the norm of increment, we used the method of rolling average with an 11-year period of averaging. At the second stage we calculated relative indices of annual increments using the formula $I=$ if $/$ is $\times 100 \%$, where $I$-relative index, \%; if - actual width of annual ring (mm), is - rolled width of annual ring (the norm of increment for particular year, $\mathrm{mm}$ ).

To determine the influence of the environmental factors on radial growth, we calculated the indices of abnormal radial increments for 10year periods. The ratio of the sum of the deviations of relative indices of increments greater than $100 \%$ of the norm to the sum of deviations of relative indices of increments lower than $100 \%$ of the norm, expressed in percent gives a number of indices which characterize the abnormality of the environmental conditions over a studied period (Lovelius, 1979).

To determine the synchronicity (parallelism) of changes in radial increments of both tree stands of different forest types which grow in similar type of conditions of growth location, we distinguished mutual years when the increments were greater or smaller than $100 \%$ of the norm and calculated the correlation coefficient.

\section{Results}

Detailed examination of the sanitary condition revealed that weakened trees of European spruce form the tree stand in the monitoring plot No 1 , severely weakened - monitoring plot No 2. Of the different types of damage to the trees, the commonest were broken crown, mechanical damage, resin bleeding, damage caused by bark beetles.

The graph of the curves of absolute annual radial increments of the model trees (Fig. 2) shows that the trees in the first monitoring plot at the beginning of growth had different increments ranging 1.22-4.40 mm. In the period 1965-1990, all the trees had the increment of less than $2.00 \mathrm{~mm}$. Similar reaction of trees of different ages to the external factors indicates that the conditions were unsatisfactory for growth. After 1990 (likely as a result of thinning out of the tree stand to the stand density of 0.4 ), most of the trees in this object have increased the increment. At the second monitoring plot, all the trees had the highest increments at the beginning of the growth, which, with certain fluctuations, have decreased with time. The lowest increments of the trees (except trees No 7 and 9) occurred in the recent 20 years.

Table 1

Characteristic of constant monitoring plots

\begin{tabular}{|c|c|c|c|c|c|c|c|c|c|}
\hline $\begin{array}{l}\text { No of constant object of the } \\
\text { survey, data of coring extraction }\end{array}$ & $\begin{array}{l}\text { Compartment/ } \\
\text { subcompartment }\end{array}$ & $\begin{array}{c}\text { Forest type, } \\
\text { stand composition }\end{array}$ & $\begin{array}{c}\text { Height above } \\
\text { the sea level }\end{array}$ & $\begin{array}{l}\text { Steepness of the } \\
\text { slope, degrees }\end{array}$ & $\begin{array}{l}\text { Age, } \\
\text { years }\end{array}$ & $\begin{array}{c}\text { Average } \\
\text { diameter, } \mathrm{cm}\end{array}$ & $\begin{array}{l}\text { Average } \\
\text { height, } m\end{array}$ & $\begin{array}{c}\text { Bonitat } \\
\text { (site quality)* }\end{array}$ & $\begin{array}{c}\text { Stand } \\
\text { density }\end{array}$ \\
\hline $\begin{array}{c}1, \\
19.06 .2018\end{array}$ & $26 / 62$ & $\begin{array}{l}\text { humid spruce forest } \\
\text { type, } 10 \text { spruce }\end{array}$ & 1350 & 20 & 162 & 42 & 27 & II & 0.4 \\
\hline $\begin{array}{c}2, \\
20.06 .2018\end{array}$ & $25 / 20$ & $\begin{array}{l}\text { humid beech-fir } \\
\text { mixed spruce forest, } \\
8 \text { spruce } 2 \text { fir }\end{array}$ & 1175 & 25 & 118 & 36 & 30 & I & 0.6 \\
\hline
\end{tabular}

Note: * - here bonitat refers to the parameter of forest productivity which depends on the soil and climatic characteristics of growing location; it is calculated as average height of trees of dominating tree species in the forest taking into consideration of its age; the I and II classes of bonitat indicate high productivity, III-IV - average productivity, V - low productivity, $\mathrm{Va}$ and $\mathrm{Vb}$ - nonproductive. 

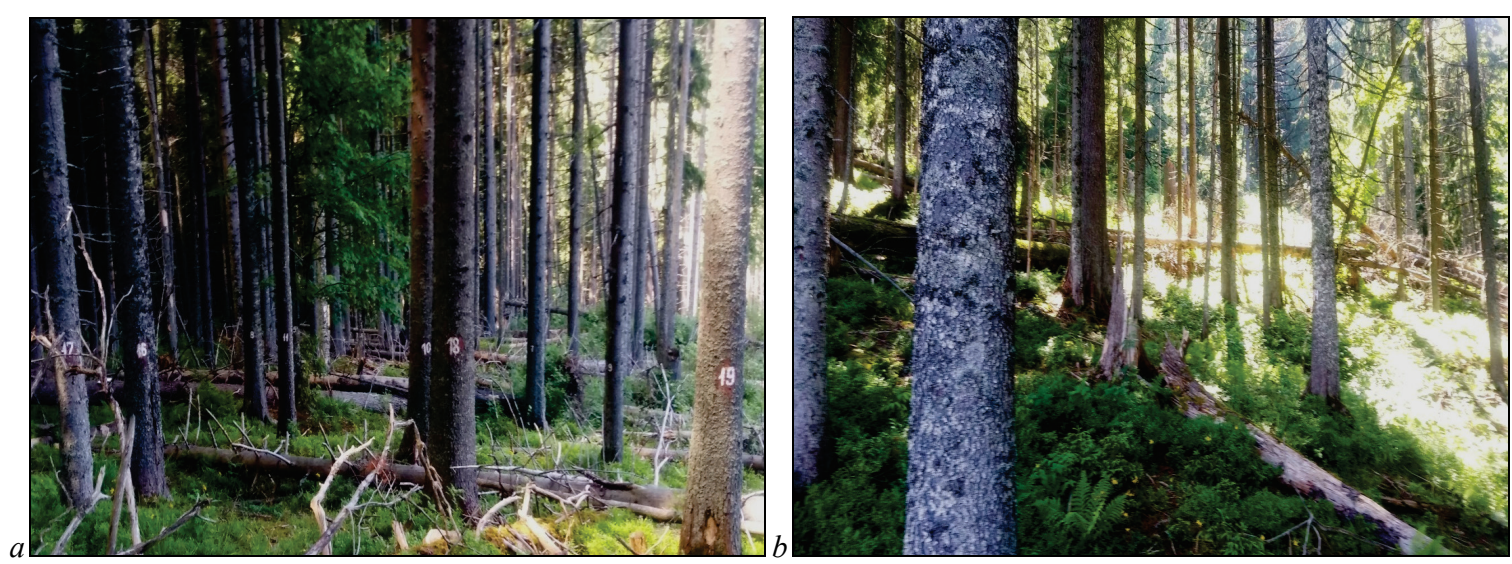

Fig. 1. Condition of the tree stands in the monitoring plots: $a$-weakened tree stand (monitoring plot No 1), $b$-severely weakened tree stand (monitoring plot No 2 )

Annual radial increments of the model trees in the first monitoring plot ranged $0.19-4.46 \mathrm{~mm}$ (Table 2). The greatest increments in the trees occurred in 1925-1963 (5 trees) and 2002-2013 (4 trees). The lowest increments in the trees took place in 1982-1983 (5 trees) and 2006-2016 ( 3 trees). Average increments ranged $0.88-1.96 \mathrm{~mm}$. Variation coefficients indicate that the most stable increment occurred in the trees aged over 80 years (variation coefficients $-30.8-45.9 \%$ ), highest fluctuations in the increment were seen in the trees of the age 60-80 years (variation coefficients $-42.1-58.9 \%$ ). The range of fluctuations of annual increments in the trees in the second monitoring plot was somewhat higher compared with the first one, measuring $0.15-5.49 \mathrm{~mm}$. The greatest increments for all the trees occurred in 1939-1977. In the majority of the trees (6 of 9 trees), the smallest increments were observed for 2012-2016, in 2 other trees - 1988-1989. Average increment ranged $1.06-1.78 \mathrm{~mm}$. Variation coefficients of the mean radial increments of the trees (38.9-82.7\%) in this, severely weakened, tree stand were higher than in the trees of the weakened stand of trees $(30.8-58.9 \%)$. In general, fluctuations of the increment in the trees of both tree stands were significant. The smallest increments occurred in 1982-1991 (44.4\% of the trees) and 2012-2016 (38.9\% of the trees). All the model trees have a right-side asymmetric pattern of annual radial increments (Table 2). Insignificant asymmetry of the distribution of the increments approximated to the normal (the asymmetry coefficient of 0.07 ) was seen only in one tree. Moderate asymmetry was observed in three trees (asymmetry coefficients equaled 0.31, 0.32, 0.44 ). The rest of the trees had significant asymmetry of the distribution of the increments. Two thirds of the model trees had positive excess (sharpapical form) of the distribution of the annual radial increments, one thirdnegative excess (flat-apical form).

To characterize the course of the growth of the tree stands, the data of measurements of the tree ring series in the model trees which represent these tree stands were averaged according to the calendar years, obtaining two generalized tree-ring chronologies of 97 years duration (1921-2017, monitoring plot No 1) and 81 years (1937-2017, monitoring plot No 2, Fig. 3). Annual increment of the weakened tree stand (monitoring plot No 1) was the greatest in the first age class $(2.00-3.39 \mathrm{~mm})$, with time decreased to $0.86 \mathrm{~mm}$ (1982). In the following years it increased to $1.9 \mathrm{~mm}$ (2014), since 2015 it decreased, equaling $1.19 \mathrm{~mm}$ in 2017. Average increment of the tree stand for the surveyed period was $1.78 \mathrm{~mm} /$ year. Annual increment in the severely weakened tree stand (monitoring plot No 2) was also the greatest in the first age class. In the same class, it had notable decrease (from $4.36 \mathrm{~mm}$ in 1939 it reduced to $1.89 \mathrm{~mm}$ in 1957). From 1958 to 1978, the increment with insignificant fluctuations was stable (within $2.00 \mathrm{~mm}$ ). During the period from 1979 to 2003 , the increment was decreasing and remained stably low over the last 20 years. Average increment of the tree stand for the surveyed period was $1.84 \mathrm{~mm} /$ year. Over the last 10 years, the average increment in the tree stands in this plot decreased by $54.9 \%$ compared with the average increment of the tree stand throughout the surveyed period (81 years), whereas the average increment in the weakened tree stand in the first monitoring plot decreased only by $7.9 \%$ over the last 10 years compared with the average increment of the tree stand throughout the study period ( 97 years, Table 3). To exclude the differences in the tempi of growth of trees (exclu- sion of age factor) and adjustment of the measurements of the radial increment of tree ring chronologies to the comparative values, we performed standardization of the data. The curves of the increments and the increment norms (Fig. 4) indicate that the most extreme period for the weakened tree stand in the monitoring plot No 1 was 1921 to 1954, when the increments, as well as the norms of increments $(2.81-2.06 \mathrm{~mm})$ were the greatest. The most extreme period for the severely weakened tree stand (monitoring plot No 2) was 1939-1978, when it had the greatest annual increments and increment norms $(3.43-1.97 \mathrm{~mm})$.

The indices of annual increments reflect the fluctuations of increments around the line of the average 100\% increment. The determined data of the extremes of the increment help in evaluating its relationship with the environmental factors. The indices of the increment of tree stands in the monitoring plots show the period of the expressions and depressions that occurred in the years with clear minimums and peaks (Fig. 5). According to the duration of the cycles and scales of the deviations from the norm, two types of fluctuations were distinguished: 5-6-year strong and 1-3-year small types. The fluctuations of the most indices of increment of trees in both stands do not exceed $15 \%$ of the annual norm of increments, the fluctuations of the most indices were within 5-10\% compared with the norm. The duration of the cycles of the increment in the tree stands was $6-$ 13 years in the first monitoring plot, and 9 years average cycle. The duration of the cycles in the second monitoring plot was 3-11 years, average cycle accounted for 7 years.

To determine the influence of the environmental factors on the radial increment, we calculated the indices of abnormality of the radial increments for ten-year periods (Table 4). The abnormality indices characterize the abnormality of the conditions for the surveyed period. The values of the conditional increment indices higher than $100 \%$ characterize positive effect of the environmental factors on the radial growth, lower than $100 \%$ negative effect. The fluctuations of the increment indices in relation to $100 \%$ norm in both monitoring plots for ten-year periods were similar, being within $83.8-114.6 \%$. Over the recent several decades, favourable conditions for the growth of the trees in both monitoring plots occurred in 1991-2010, unfavourable in 2011-2017. The most unfavourable period for the tree growth was 1981-1990 (abnormality indices were $28.3 \%$ in the monitoring plot No 1 and $50.0 \%$ in the monitoring plot No 2).

To determine the synchronicity (parallelism) of the changes in the radial increments of the trees of the both stands of different types of forest (humid spruce forest type in the monitoring plot No 1 and humid beech-fir mixed spruce forest - monitoring plot No 2), which grow in similar conditions of growth locations (humid relatively fertile site type), we determined common years when the increments were greater and smaller than $100 \%$ of the norm (Table 5 ). For the surveyed period ( 81 years), the annual increments in spruce in the two monitoring plots were synchronous for 49 years (or $60.5 \%$ of the surveyed period). Out of them, during 21 years, the indices of increment were greater than $100 \%$ of the norm. Over the last 8 years, only the increments smaller than $100 \%$ of the norm coincided. The calculated coefficient of the correlation $(r=0.56)$ indicates that the similar type of the growth conditions (humid relatively fertile site type) has a significant effect on the formation and variability of increments in the process of the trees' life cycle. 


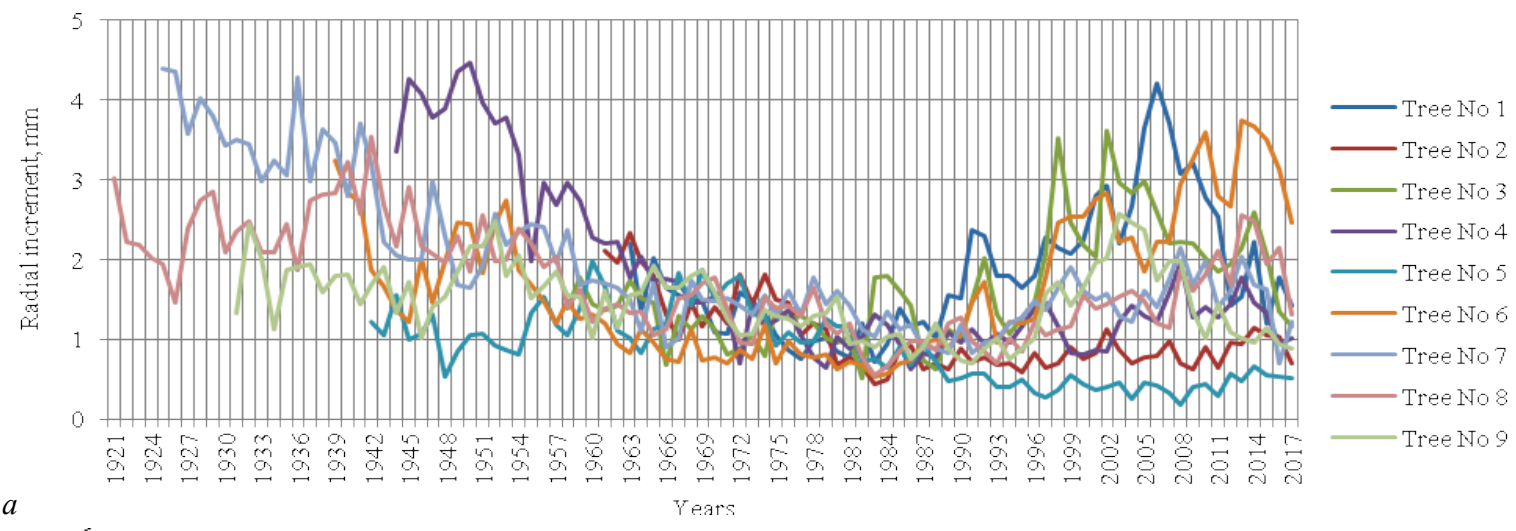

$a$

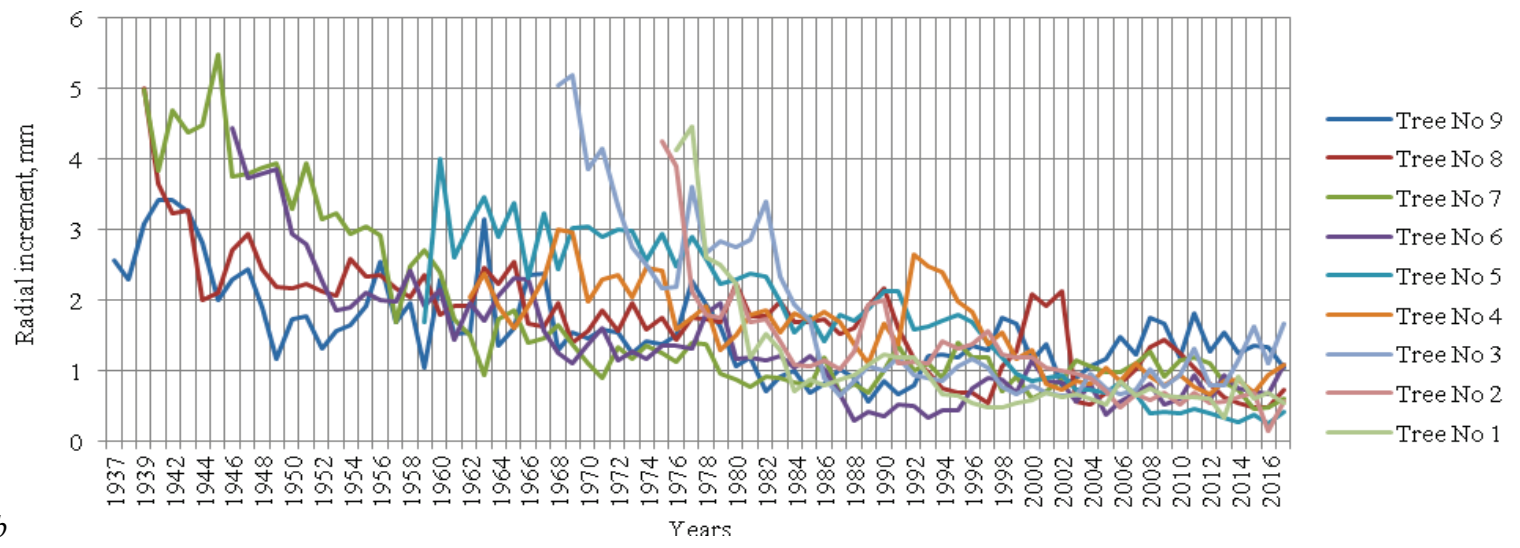

Fig. 2. Dynamics of absolute annual radial increments in the model trees of European spruce in the monitoring plots:

$a$-dynamics of absolute annual radial increments of model trees of European spruce in the monitoring plot No 1 (weakened tree stand),

$b$-dynamics of absolute annual increments of the model trees of European spruce in the monitoring plot No 2 (severely weakened tree stand)

Table 2

Characteristics and indicators of radial growth in the model trees of European spruce in the monitoring plots

\begin{tabular}{|c|c|c|c|c|c|c|c|c|c|c|c|}
\hline \multirow{3}{*}{ No of trees } & \multirow{3}{*}{$\begin{array}{l}\text { Age, } \\
\text { years }\end{array}$} & \multirow{3}{*}{$\begin{array}{l}\text { Diameter, } \\
\mathrm{cm}\end{array}$} & \multicolumn{4}{|c|}{ Indicators of radial growth, $\mathrm{mm}$} & \multirow{3}{*}{$\begin{array}{l}\text { Average radial } \\
\text { increment of the } \\
\text { tree, } \mathrm{mm}\end{array}$} & \multirow{3}{*}{$\begin{array}{c}\text { Standard } \\
\text { deviation, } \mathrm{mm}\end{array}$} & \multirow{3}{*}{$\begin{array}{c}\text { Variation } \\
\text { coefficient of radial } \\
\text { increment, } \%\end{array}$} & \multirow{3}{*}{$\begin{array}{c}\text { Asymmetry } \\
\text { coefficient }\end{array}$} & \multirow{3}{*}{$\begin{array}{c}\text { Excess } \\
\text { coefficient }\end{array}$} \\
\hline & & & \multicolumn{2}{|c|}{ maximum } & \multicolumn{2}{|c|}{ minimum } & & & & & \\
\hline & & & $\mathrm{mm}$ & year & $\mathrm{mm}$ & year & & & & & \\
\hline \multicolumn{12}{|c|}{ Monitoring plot No. 1 (weakened tree stand) } \\
\hline 1 & 55 & 28.5 & 4.21 & 2006 & 0.73 & 1983 & 1.80 & 0.636 & 44.3 & 0.98 & 0.51 \\
\hline 2 & 57 & 19.4 & 2.33 & 1963 & 0.45 & 2006 & 1.04 & 0.436 & 42.1 & 1.20 & 0.67 \\
\hline 3 & 60 & 20.3 & 3.61 & 2002 & 0.52 & 1982 & 1.63 & 0.686 & 42.1 & 0.90 & 0.50 \\
\hline 4 & 74 & 28.3 & 4.46 & 1950 & 0.63 & 1983 & 1.76 & 1.036 & 58.9 & 1.28 & 0.43 \\
\hline 5 & 76 & 18.0 & 1.98 & 1960 & 0.19 & 2008 & 0.88 & 0.446 & 50.4 & 0.52 & -0.59 \\
\hline 6 & 79 & 29.4 & 3.75 & 2013 & 0.53 & 1983 & 1.69 & 0.888 & 52.6 & 0.61 & -0.79 \\
\hline 7 & 93 & 40.5 & 4.40 & 1925 & 0.70 & 2016 & 1.96 & 0.901 & 45.9 & 1.08 & 0.26 \\
\hline 8 & 97 & 43.5 & 3.54 & 1942 & 0.55 & 1983 & 1.73 & 0.644 & 37.2 & 0.44 & -0.48 \\
\hline 9 & 87 & 72.0 & 2.57 & 2003 & 0.70 & 1991 & 1.48 & 0.455 & 30.8 & 0.32 & -0.64 \\
\hline \multicolumn{12}{|c|}{ Monitoring plot No. 2 (severely weakened tree stand) } \\
\hline 1 & 42 & 15.7 & 4.47 & 1977 & 0.33 & 2013 & 1.06 & 0.880 & 82.7 & 2.59 & 0.57 \\
\hline 2 & 43 & 16.1 & 4.26 & 1975 & 0.15 & 2016 & 1.27 & 0.786 & 62.1 & 2.05 & 0.38 \\
\hline 3 & 50 & 19.9 & 5.20 & 1969 & 0.64 & 2003 & 1.71 & 1.193 & 69.8 & 1.28 & 2.21 \\
\hline 4 & 56 & 22.2 & 3.01 & 1968 & 0.66 & 2012 & 1.59 & 0.618 & 38.9 & 0.31 & 1.85 \\
\hline 5 & 59 & 24.4 & 4.01 & 1960 & 0.26 & 2016 & 1.78 & 1.001 & 56.1 & 0.07 & -1.09 \\
\hline 6 & 72 & 26.9 & 4.44 & 1946 & 0.30 & 1988 & 1.37 & 0.890 & 64.7 & 1.38 & -0.80 \\
\hline 7 & 79 & 33.4 & 5.01 & 1939 & 0.48 & 2016 & 1.77 & 0.808 & 45.7 & 0.88 & 0.78 \\
\hline 8 & 79 & 35.2 & 5.49 & 1945 & 0.46 & 2015 & 1.78 & 1.261 & 71.4 & 1.28 & 5.20 \\
\hline 9 & 81 & 42.3 & 3.43 & 1942 & 0.57 & 1989 & 1.61 & 0.668 & 41.5 & 1.03 & 6.39 \\
\hline
\end{tabular}

Table 3

Indicators of average radial growth increments in the tree stands of European spruce in the monitoring plots and their variability

\begin{tabular}{lcc}
\hline \multicolumn{1}{c}{ Indicators of increment in the stand of trees } & Monitoring plot No. 1 (weakened tree stand) & Monitoring plot No.2 (severely weakened tree stand \\
\hline Average increment in the tree stand for the surveyed period, mm/year & 1.78 & 1.84 \\
Standard deviation, mm & 0.622 & 0.864 \\
Variation coefficient, $\%$ & 35.00 & 46.90 \\
\hline Average increment in the tree stand for the last 20 years (1998-2017), mm/year & 1.67 & 0.88 \\
Standard deviation, mm & 0.174 & 0.113 \\
Variation coefficient, $\%$ & 10.40 & 12.90 \\
\hline Average increment in the tree stand for the last 10 years (2008-2017), mm/year & 1.64 & 0.83 \\
Standard deviation, mm & 0.215 & 0.094 \\
Variation coefficient, $\%$ & 13.15 & 11.35 \\
\hline
\end{tabular}




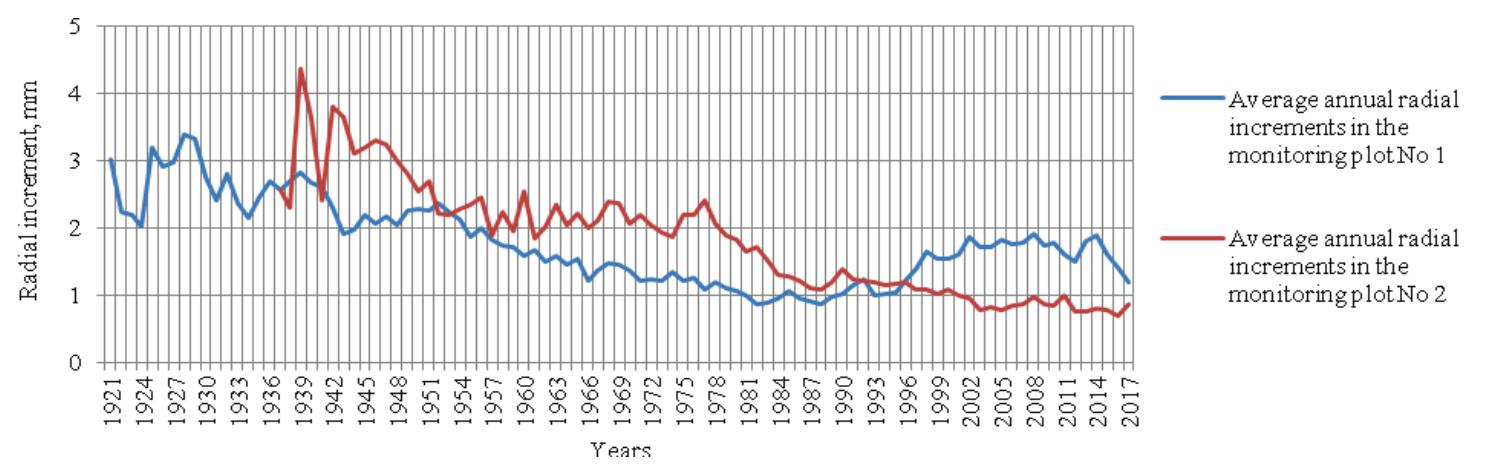

Fig. 3. Generalized tree-ring chronologies of European spruce in the monitoring plots

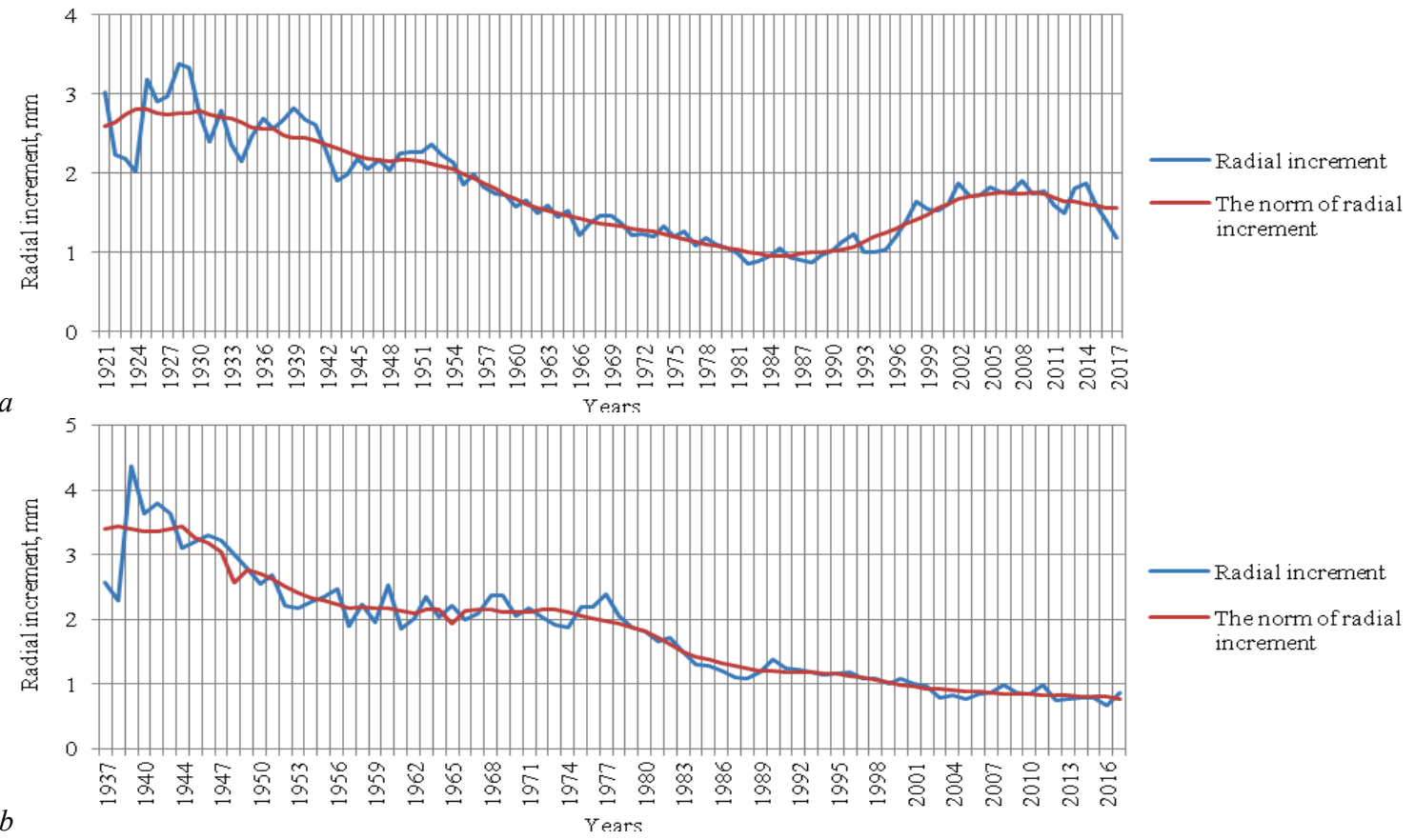

Fig. 4. Dynamics of annual increments and annual norms of increments in the tree stands of European spruce in the monitoring plots: $a$-dynamics of annual radial increment and annual norm of increment in the tree stand of European spruce in the monitoring plot No 1 (weakened tree stand), $b$-dynamics of annual radial growth and annual norm of the increment in the tree stand of European spruce in the monitoring plot No 2 (severely weakened tree stand)

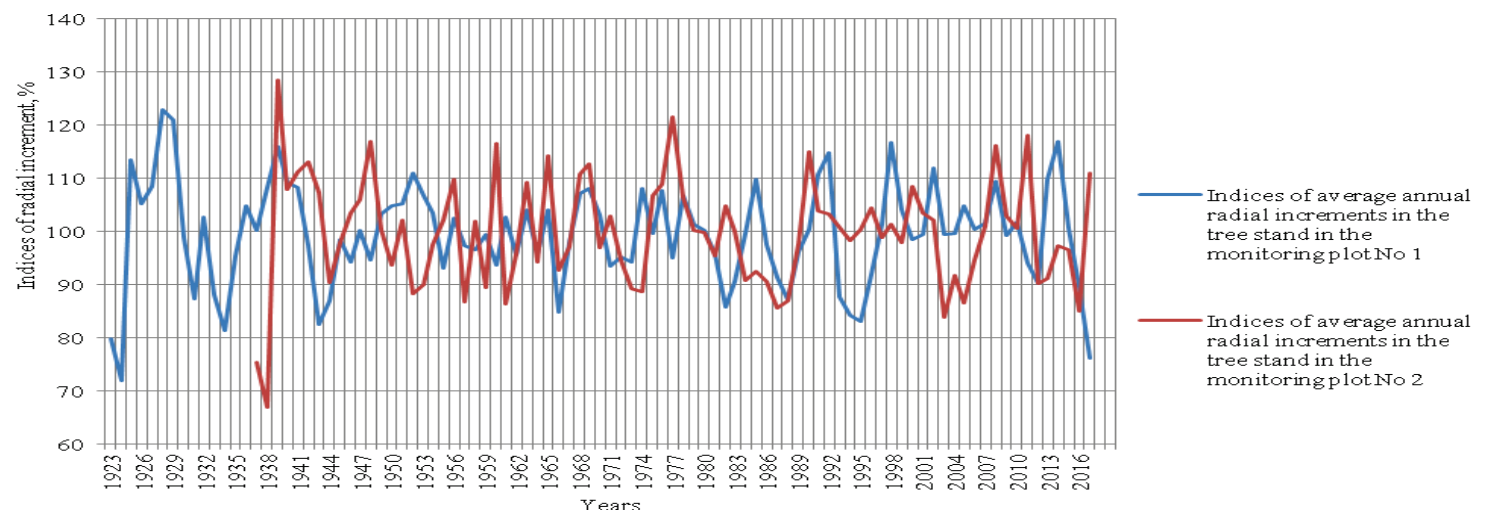

Fig. 5. Indices of annual increments in the tree stands in the monitoring plots

\section{Discussion}

The conducted studies were focused on the radial increment in the trees of European spruce and its dynamics in tree stands in different sanitary condition, identification of abnormal growth periods of the trees, and cyclicity of the increments for further substantiation of the forestry measures. Radial increment of European spruce in the Carpathians is affected by a significant number of natural and anthropogenic factors which have a complex synergic effect and underlie the condition of spruce forests. Re- gional synchronization of radial increment of the old-growth forest of Picea abies along the Carpathian arc showed temporal fluctuations of the increment throughout the XX century. The increment in the trees for the most part increased with rises in the temperature, being a sign of the transition of areas of the mountain ranges from limitation of the temperature to limitation of moisture (Schurman et al., 2019). Our studies revealed that annual increments of the model trees in the monitored plots significantly vary, ranging $0.15-5.49 \mathrm{~mm}$ (Fig. 2, Table 2). At the border between Poland and Slovakia, in the Western Carpathians, the divergence of the 
growth of neighbouring trees of European spruce was studied, i.e. expression of the growth tendencies of the neighbouring trees. Non-homogeneity of soil, genetics and air pollution are viewed as the main possible mechanisms of divergence of the growth of spruce (Buras et al., 2018). Studies on the radial increment of the old-growth forest of the European spruce in the Carpathian arc demonstrated that the residual dispersion of an unknown nature is the most notable dispersion in some Carpathian spruces, but with broader spatial hierarchies the climatic dispersion dominates (Bjorklund et al., 2019).

Trees of one type of forest have similar patterns of formation of radial increments. The studies revealed the dependence of increment on the age of trees and their location within the tree stands. Therefore, in the first mo- nitoring plot, the trees older than 60 years had the greatest increments in the first decades of growth (1921-1954), younger trees - in the last twenty years (1997-2017), probably after the thinning-out of the tree stand. In the second monitoring plot, all the model trees had their greatest increments in the first 20-year period of growth. However, during that period, the trees older than 60 years had the greatest increments; increments in the trees of the age of 40-60 years were smaller than in the 60-years old trees; the lowest increments in that period were seen in 40-year old trees, suggesting that with time the older trees dominated, therefore worsening the conditions of growth of younger trees. In general, in both monitoring plots, the smallest increments were seen for $1982-1991$ (in $44.4 \%$ of the trees) and in $2012-2016$ (in $38.9 \%$ of the trees).

Table 4

Indices of radial increments in European spruce over the ten-year periods

\begin{tabular}{|c|c|c|c|c|c|c|c|}
\hline \multirow[b]{2}{*}{ Years } & \multicolumn{3}{|c|}{ Indices lower than the norm $(100 \%)$} & \multicolumn{3}{|c|}{ Indices higher than the norm $(100 \%)$} & \multirow[b]{2}{*}{$\begin{array}{l}\text { Index of abnormality } \\
\text { of redial increment, } \%\end{array}$} \\
\hline & $\begin{array}{l}\text { number } \\
\text { of years }\end{array}$ & $\begin{array}{l}\text { total of increment } \\
\text { of indices, } \%\end{array}$ & $\begin{array}{l}\text { average increment } \\
\text { index, } \%\end{array}$ & $\begin{array}{l}\text { number } \\
\text { of years }\end{array}$ & $\begin{array}{l}\text { total of increment } \\
\text { of indices, } \%\end{array}$ & $\begin{array}{l}\text { average increment } \\
\text { index, } \%\end{array}$ & \\
\hline \multicolumn{8}{|c|}{ Monitoring plot No 1 (weakened tree stand) } \\
\hline $1921-1930$ & 4 & 335.0 & 83.8 & 6 & 687.9 & 114.6 & 205.3 \\
\hline $1931-1940$ & 4 & 352.4 & 88.1 & 6 & 641.3 & 106.9 & 182.0 \\
\hline $1941-1950$ & 6 & 554.5 & 92.4 & 4 & 417.0 & 104.2 & 75.2 \\
\hline $1951-1960$ & 5 & 480.5 & 96.1 & 5 & 529.3 & 105.9 & 110.1 \\
\hline $1961-1970$ & 4 & 374.2 & 93.6 & 6 & 629.3 & 104.9 & 168.2 \\
\hline $1971-1980$ & 5 & 477.8 & 95.6 & 5 & 524.4 & 104.9 & 109.7 \\
\hline $1981-1990$ & 8 & 744.6 & 93.1 & 2 & 210.3 & 105.2 & 28.3 \\
\hline $1991-2000$ & 5 & 445.8 & 89.2 & 5 & 548.0 & 109.6 & 122.9 \\
\hline $2001-2010$ & 4 & 398.1 & 99.5 & 6 & 629.9 & 105.0 & 158.2 \\
\hline 2011-2017 & 4 & 350.1 & 87.5 & 3 & 327.4 & 109.1 & 93.5 \\
\hline \multicolumn{8}{|c|}{ Monitoring plot No 2 (severely weakened tree stand) } \\
\hline $1941-1950$ & 3 & 282.0 & 94.0 & 7 & 758.6 & 108.4 & 269.0 \\
\hline $1951-1960$ & 5 & 452.4 & 90.5 & 5 & 532.7 & 106.5 & 117.8 \\
\hline $1961-1970$ & 6 & 563.4 & 93.9 & 4 & 447.0 & 111.8 & 79.4 \\
\hline 1971-1980 & 4 & 372.8 & 93.2 & 6 & 647.0 & 107.8 & 173.6 \\
\hline 1981-1990 & 7 & 640.0 & 91.4 & 3 & 320.1 & 106.7 & 50.0 \\
\hline $1991-2000$ & 3 & 295.2 & 98.4 & 7 & 723.0 & 103.3 & 244.9 \\
\hline $2001-2010$ & 4 & 357.0 & 89.3 & 6 & 626.8 & 104.5 & 175.6 \\
\hline 2011-2017 & 5 & 460.8 & 92.2 & 2 & 229.2 & 114.6 & 49.8 \\
\hline
\end{tabular}

Table 5

Synchronous years of radial increments in European spruce in the monitoring plots

\begin{tabular}{|c|c|c|c|c|c|}
\hline \multirow[b]{2}{*}{$\begin{array}{l}\text { Years of maxima } \\
\text { of increment indices }\end{array}$} & \multicolumn{2}{|c|}{ Increment indices higher than $100 \%$ norm, $\%$} & \multirow[b]{2}{*}{$\begin{array}{l}\text { Years of minimum } \\
\text { increment indices }\end{array}$} & \multicolumn{2}{|c|}{ Increment indices lower than $100 \%$ norm, $\%$} \\
\hline & $\begin{array}{l}\text { monitoring plot No } 1 \\
\text { (weakened tree stand) }\end{array}$ & $\begin{array}{c}\text { monitoring plot No } 2 \\
\text { (severely weakened tree stand) }\end{array}$ & & $\begin{array}{l}\text { monitoring plot No } 1 \\
\text { (weakened tree stand) }\end{array}$ & $\begin{array}{c}\text { monitoring plot No } 2 \\
\text { (severely weakened tree stand) }\end{array}$ \\
\hline 1939 & 115.98 & 128.56 & 1944 & 87.09 & 90.38 \\
\hline 1940 & 109.26 & 107.89 & 1945 & 98.53 & 97.91 \\
\hline 1947 & 100.34 & 106.01 & 1957 & 97.33 & 86.76 \\
\hline 1949 & 103.38 & 100.50 & 1959 & 99.53 & 89.58 \\
\hline 1951 & 105.25 & 102.09 & 1959 & 99.53 & 89.58 \\
\hline 1956 & 102.58 & 109.96 & 1962 & 95.57 & 95.79 \\
\hline 1963 & 104.11 & 109.27 & 1964 & 95.88 & 94.21 \\
\hline 1965 & 104.08 & 114.24 & 1966 & 84.83 & 92.83 \\
\hline 1968 & 107.09 & 110.81 & 1967 & 97.92 & 97.11 \\
\hline 1969 & 108.15 & 112.70 & 1957 & 97.33 & 86.76 \\
\hline 1976 & 107.78 & 108.84 & 1959 & 99.53 & 89.58 \\
\hline 1978 & 106.74 & 106.48 & 1962 & 95.57 & 95.79 \\
\hline 1979 & 101.51 & 100.36 & 1964 & 95.88 & 94.21 \\
\hline 1990 & 100.45 & 115.01 & 1966 & 84.83 & 92.83 \\
\hline 1991 & 110.78 & 103.94 & 1967 & 97.92 & 97.11 \\
\hline 1992 & 114.95 & 103.30 & 1972 & 95.28 & 94.68 \\
\hline 1998 & 116.72 & 101.47 & 1973 & 94.22 & 89.33 \\
\hline 2002 & 111.92 & 102.17 & 1981 & 95.78 & 95.40 \\
\hline 2007 & 101.62 & 101.12 & 1984 & 99.72 & 90.91 \\
\hline 2008 & 109.48 & 116.31 & 1986 & 97.64 & 90.69 \\
\hline 2010 & 101.72 & 100.71 & 1987 & 91.41 & 85.61 \\
\hline- & - & - & 1988 & 87.24 & 87.07 \\
\hline- & - & - & 1989 & 96.21 & 97.76 \\
\hline- & - & - & 1994 & 84.23 & 98.39 \\
\hline- & - & - & 2003 & 99.58 & 84.00 \\
\hline- & - & - & 2004 & 99.68 & 91.76 \\
\hline- & - & - & 2012 & 90.35 & 90.30 \\
\hline- & - & - & 2016 & 89.42 & 85.13 \\
\hline Average & 106.85 & 107.70 & Average & 94.57 & 91.84 \\
\hline
\end{tabular}

Over the last few years, the increment in spruce in the monitoring plots has decreased, which could be the consequence of drought, air pollution or other factors. In 2015, as a result of the extremely hot summer in the Central Europe, the radial growth of European spruce in the Central Alps in Switzerland decreased in the plots located lower than $1,500 \mathrm{~m}$ above the sea level (Burri et al., 2019). In the Eastern Carpathians, the 
growth-limiting factor for the tree stands of spruce at all the stages of succession was winter drought. Frequency and scales of the natural disturbances, as well as droughts, are expected to increase with climate changes (Svobodova et al., 2019). In the mountains of the Eastern Tatras (Western Carpathians, Slovakia) during the vegetation period of 2014, at the heights of $810 \mathrm{~m}$ to $1,778 \mathrm{~m}$ above the sea level, a high phytotoxic potential of $\mathrm{O}_{3}$ was determined, which increased with height above the sea level and had negative effect on the increment of European spruce (Bicarova et al., 2016).

The studied tree stands have similar patterns of the formation and variation in the radial increments. Therefore, annual increments in the tree stands in the both plots were almost the same, equaling $1.78 \mathrm{~mm} /$ year (weakened tree stand) and $1.84 \mathrm{~mm} /$ year (severely weakened tree stand). The slightly smaller increment in the first monitoring plot is explained by the long depressive period the tree stand underwent from 1965 to 1990 , when all the trees had the increment lower than $2.00 \mathrm{~mm}$. The similar reaction of the trees of different age to external factors indicates that the conditions were unfavourable for growth. After 1990 (probably as a result of thinning-out of the tree stand to 0.4 stand density), increment in most trees in that plot increased. Increased increment of European spruce after 1990 was determined in the Western Carpathians. This increment is explained by the frequency of disturbances in highland forests sensitive to the environmental changes (Parobekova et al., 2016).

The severely weakened tree stand in the second monitoring plot was younger (118 years) than the first one (162 years) and had denser stand density (0.6). Average increment in the tree stand in the second plot over the last 10 years fell by $54.9 \%$ (Table 3 ) compared with the average increment in the tree stand throughout the surveyed period ( 81 years), whereas the average increment in the weakened tree stand in the first monitored plot decreased by $7.9 \%$ over the last 10 years compared with the average increment in the tree stand throughout the surveyed period (97 years), suggesting that the tree stands in the monitored plots undergo different stages of the succession: the first one - stage of recovery after disturbance, the second one - stage of disturbance. Variation coefficients of average radial increments in the model trees of spruce in mixed tree stand in the second monitoring plot were higher (38.9-82.7\%) than in the first one (30.8-58.9\%), which also indicates a vulnerable tree stand. Natural subalpine forests are sensitive to the climate changes. In the Eastern Carpathians, according to the results of inventory checking of the forests, there were determined patterns of the radial increments in the trees in the mixed coniferous forest (Picea abies and Pinus cembra). Discrete disturbances (large-scale or small-scale), as well as chronic disturbances (climate change), were determined as the leading forces of the development of the structure of tree stands (Popa et al., 2017).

Fluctuations in the mean indices of increment in relation to $100 \%$ norm in the both monitoring plots over the ten year periods were similar, within $83.8-114.6 \%$ (Table 4). The studies revealed that over the last several decades favourable conditions for growth of spruce in the monitoring plots occurred in 1991-2010, unfavourable - 2011-2017. The most unfavourable period for the growth of the trees was 1981-1990 (indices of abnormality equaled $28.3 \%$ - monitoring plot No 1 and 50.0\% - monitoring plot No 2). Abnormally low increment in spruce in the monitoring plots in 1981-1990 could be related to the sedimentation of the polluting substances, which were critical in the Carpathians in those years. In the Sudetes, Western and Eastern Carpathians, the role of mist in the sedimentation of hazardous substances and their effect on the increment in European spruce was studied. The width of the annual rings was analyzed over three decades: to intense pollution of the environment with hazardous substances (1950-1960), during intense pollution (1980-1990) and after pollution (2000-2010). The studies revealed that the narrowest annual rings of spruce formed in 1980s in the regions where the mist was the main source of the sedimentation of the polluting substances (Myskow et al., 2019).

Out of a number of factors which affect the width of annual rings, the main are change in the age (intense growth of young conifers, average-age trees, slowing in the growth of the mature trees, death of old trees) and change in the climatic factors which lead to an uneven course of the formation of the width of annual rings, with quasi-fluctuating (cycling) pattern instead. Annual increment in the trees is a discrete cyclic process. For the increment of the trees, the most characteristic cycles equal 80 90 years (age), 30-35 years (Brückner's cycle), 22 years (Hale cycle or the magnetic cycle of solar activity), 11 years (Schwabe-Wolf solar cycle), and also the shorter cycles: 5-6-years, 3-4-years, 2-3-years. A major part of the cyclic changes in the growth of trees is associated with the solar activity (sum of physical phenomena occurring in the Sun) which manifest in the Earth through the changes in the atmosphere circulation, which in turn, changes the thermal regime and the conditions of moisture. Cycles of increment in the tree stands in the monitoring plots were determined according to the graphs of the indices of annual radial increments (Fig. 5). Duration of the cycles of increment in the weakened tree stand ranged 6 to 13 years, duration of average cycle was 9 years, duration of the increment cycles in severely weakened tree stand was lower, varying 3-11 years, the duration of the average cycle accounted for 7 years. The radial increment of spruce in the Carpathians and its cycles is greatly affected by winddriven disturbances in the tree stands. In the Tatras (Western Carpathians), over the last 200 years, there were determined 13 episodes of disturbances. The study of the history of the disturbances in the spruce forests allows differentiation of the mechanical factors from the biotic factors which affect the radial growth (Holeksa et al., 2016).

Over the surveyed period (81 years), the annual increment of the spruce in the two monitoring plots was synchronous for 49 years (or $60.5 \%$ of the studied period). Out of them, for 21 years the increment indices were higher than the $100 \%$ norm, 28 years - lower than the $100 \%$ norm. The fact that over the last 8 years, only the increments less than $100 \%$ of the norm of the increment coincided indicates that the conditions in that period were unfavourable for the growth of the trees. The calculated correlation coefficient $(r=0.56)$ indicates that the similar type of the conditions of growth location (humid relatively fertile site type) has a significant effect on the formation and variability of the increments in the process of the trees' life cycle.

To summarize, we should note that dendrochronological studies require complex information about the natural and anthropogenic factors which could have an effect on the radial growth of trees and its variability.

\section{Conclusions}

The research revealed that over the last several decades the favourable conditions for the growth of European spruce occurred in 1991-2010, unfavourable - in 2011-2017, very unfavourable - 1981-1990. Average radial increment of spruce in the weakened tree stand over the last 10 years decreased by $7.9 \%$, in severely weakened tree stand - by $54.9 \%$ compared with the average increments in the tree stands over the surveyed periods, suggesting that the tree stands undergo different stages of succession: the weakened tree stand undergoes the stage of recovery after disturbance, the severely weakened tree stand - stage of disturbance. The studies showed the dependence of the radial increment on the sanitary condition of the tree stands. The results of the studies could be used for the evaluation of dynamic processes in the forest ecosystems as a result of the influence of different factors and planning of the forestry measures.

\section{References}

Bicarova, S., Sitkova, Z., \& Pavlendova, H. (2016). Ozone phytotoxicity in the Western Carpathian Mountains in Slovakia. Central European Forestry Journal, 62(2), 77-88.

Bjorklund, J., Rydval, M., Schurman, J. S., Seftigen, K., Trotsiuk, V., Jandaa, P., Mikolas, M., Dusatko, M., Cada, V., Bace, R., \& Svoboda, M. (2019). Disentangling the multi-faceted growth patterns of primary Picea abies forests in the Carpathian arc. Agricultural and Forest Meteorology, 271, 214-224.

Brygadyrenko, V. V. (2016). Effect of canopy density on litter invertebrate community structure in pine forests. Ekológia (Bratislava), 35(1), 90-102.

Buras, A., Spyt, B., Janecka, K., \& Kaczka, R. (2018). Divergent growth of Norway spruce on Babia Gora Mountain in the Western Carpathians. Dendrochronologia, 50, 33-43.

Burri, S., Haeler, E., Eugster, W., Haeni, M., Etzold, S., Walthert, L., Braun, S., \& Zweifel, R. (2019). How did Swiss forest trees respond to the hot summer 2015? Erde, 150(4), 214-229.

Cavlovic, J., Boncina, A., Božić, M., Goršić, E., Simoncic, T., \& Teslak, K. (2015). Depression and growth recovery of silver fir in uneven-aged Dinaric forests in Croatia from 1901 to 2001. Forestry, 88(5), 586-598.

Chen, L., Huang, J.-G., Stadt, K., Comeau, P., Zhai, L., Dawson, A., \& Alam, S. A. (2017). Drought explains variation in the radial growth of white spruce in Western Canada. Agricultural and Forest Meteorology, 233, 133-142. 
Ding, H., Pretzsch, H., Schutze, G., \& Rotzer, T. (2017). Size-dependence of tree growth response to drought for Norway spruce and European beech individuals in monospecific and mixed-species stands. Plant Biology, 19(5), 709-719.

Faly, L. I., Kolombar, T. M., Prokopenko, E. V., Pakhomov, O. Y., \& Brygadyrenko, V. V. (2017). Structure of litter macrofauna communities in poplar plantations in an urban ecosystem in Ukraine. Biosystems Diversity, 25(1), 29-38.

Gao, L., Zhang, C., Zhao, X., \& Zhang, L. (2017). The direct and indirect effect of fire on radial growth of Pinus koraiensis trees in a northern temperate forest of China. Dendrobiology, 78, 111-123.

Gao, W.-Q., Liu, J., Xue, Z.-M., Zhang, Y.-T., Gao, Z.-H., Ni, Y.-Y., Wang, X.-F., \& Jiang, Z.-P. (2018). Geographical patterns and drivers of growth dynamics of Quercus variabilis. Forest Ecology and Management, 429, 256-266.

Holeksa, J., Zielonka, T., Zywiec, M., \& Fleischer, P. (2016). Identifying the disturbance history over a large area of larch-spruce mountain forest in Central Europe. Forest Ecology and Management, 361, 318-327.

Holubchak, O., Korol, S., Melnychuk, I., \& Prykhodko, M. (2019). Optimization of forest ecosystem recreational services formation in conditions of decentralization in Ukraine. Advances in Economics, Business and Management Research: 2019 7th International Conference on Modeling, Development and Strategic Management of Economic System (MDSMES 2019). IvanoFrankivsk, Ukraine. Pp. 227-231.

Koval', I. M. (2006). Dendrohronologija v Ukrajini: Retrospektyva i perspektyvy rozvytku. Lisove gospodarstvo, lisova, paperova i derevoobrobna promyslovist' [Dendrochronology in Ukraine: Retrospectives and prospects for development. Forestry, forestry, paper and wood industry]. Interagency Scientific and Technical Collection, 31, 221-227 (in Ukrainian).

Latorraca, J. V., Souza, M., Silva, L. D. S. A. B., \& Ramos, L. (2015). Dendrochronology of Schizolobium parahyba (Vell.) S. F. Blake trees from Tinguá Biological Reserve - RJ. Revista Arvore, 39, 385-394.

Latreille, A., Davi, H., Huard, F., \& Pichot, C. (2017). Variability of the climateradial growth relationship among Abies alba trees and populations along altitudinal gradients. Forest Ecology and Management, 396, 150-159.

Lee, E., Wickham, C., Beedlow, P., Waschmann, R., \& Tingey, D. (2017). A likelihood-based time series modeling approach for application in dendrochronology to examine the growth-climate relations and forest disturbance history. Dendrochronologia, 45, 132-144.

Lovelius, N. V. (1979). Izmenchivost' prirosta derev'ev. Dendroindikacija prirodnyh processov i antropogennyh vozdejstvij [Variability of growth of trees. Dendroindication of natural processes and anthropogenic impacts]. Nauka, Leningrad (in Russian).

Lovelius, N. V., \& Grican, J. I. (1998). Lesnye jekosistemy Ukrainy i teplovlagoobespechennost' [Forest ecosystems of Ukraine and heat and moisture supply]. Neva, Saint Petersburg (in Russian).

Magnuszewski, M., Bijak, S., Orozumbekow, A., Howe, B., Musuraliev, K., Zasada, M., Bronisz, K., \& Bronisz, A. (2015). Different growth patterns of Picea schrenkiana subsp. tianshanica (Rupr.) Bykov and Juglans regia L. coexisting under the same ecological conditions in the Sary-Chelek Biosphere Reserve in Kyrgyzstan. Dendrobiology, 73, 11-20.

Makarenko, C. C. (2018). Ocinka dijal'nosti lisovogo gospodarstva Ukrainy u konteksti vymog chasu [Assessment of forestry activity of Ukraine in the context of time requirements]. Economy and Society, 19, 472-483 (in Ukrainian).

Matjushevskaja, E. V. (2017). Faktory izmenchivosti radial'nogo prirosta derev'ev [Variability factors for radial tree growth]. Belarusian State University, Minsk (in Russian)

Matskovsky, V. (2016). Climatic signal in tree-ring width chronologies of conifers in European Russia. International Journal of Climatology, 36(9), 3398-3406.

Mendivelso, H. A., Camarero, J. J., \& Gutierrez, E. (2016). Dendrochronology in neotropical dry forests: Methods, advances and applications. Ecosistemas, 25(2), 66-75.

Montoro Girona, M., Morin, H., Lussier, J.-M., \& Walsh, D. (2016). Radial growth response of black spruce stands ten years after experimental shelterwoods and seed-tree cuttings in boreal forest. Forests, 7(10), 240.

Moreau, G., Achim, A., \& Pothier, D. (2019). A dendrochronological reconstruction of sugar maple growth and mortality dynamics in partially cut northern hardwood forests. Forest Ecology and Management, 437, 17-26.

Myskow, E., Blas, M., Sobik, M., Godek, M., \& Owczarek, P. (2019). The effect of pollutant fog deposition on the wood anatomy of subalpine Norway spruce. European Journal of Forest Research, 138(2), 187-201.

Natalini, F., Correia, A. C., Vázquez-Piqué, J., \& Alejano, R. (2015). Tree rings reflect growth adjustments and enhanced synchrony among sites in Iberian stone pine (Pinus pinea L.) under climate change. Annals of Forest Science, 72(8), 1023-1033.

Parobekova, Z., Sedmakova, D., Kucbel, S., Pittner, J., Jaloviar, P., Saniga, M., Balanda, M., \& Vencurik, J. (2016). Influence of disturbances and climate on high-mountain Norway spruce forests in the Low Tatra Mts., Slovakia. Forest Ecology and Management, 380, 128-138.

Popa, I., Nechita, C., \& Hofgaard, A. (2017). Stand structure, recruitment and growth dynamics in mixed subalpine spruce and Swiss stone pine forests in the Eastern Carpathians. Science of the Total Environment, 598, 1050-1057.

Prykhodko, M., Havadzyn, N., Horal, L., Melnychuk, I., \& Berlous, M. (2019). Ecosystem services in the management system of ecological safety of territorial units. Advances in Economics, Business and Management Research: 2019 7th International Conference on Modeling, Development and Strategic Management of Economic System (MDSMES 2019). Ivano-Frankivsk, Ukraine. Pp. 90-95.

Rodriguez-Caton, M., Villalba, R., Srur, A. M., \& Luckman, B. (2015). Longterm trends in radial growth associated with Nothofagus pumilio forest decline in Patagonia: Integrating local - into regional - scale patterns. Forest Ecology and Management, 339, 44-56.

Rozas, V., \& Olano, J. (2017). Dendroclimatic responses of four European broadleaved tree species near their southwestern range edges. Dendrobiology, 77, 65-75.

Rybníček, M., Čermák, P., Prokop, O., Žid, T., Trnka, M., \& Kolar, T. (2016). Oak (Quercus spp.) response to climate differs more among sites than among species in Central Czech Republic. Dendrobiology, 75, 55-65.

Schurman, J. S., Babst, F., Bjrklund, J., Rydval, M., Bace, R., Cada, V., Janda, P., Mikolas, M., Saulnier, M., Trotsiuk, V., \& Svoboda, M. (2019). The climatic drivers of primary Picea forest growth along the Carpathian Arc are changing under rising temperatures. Global Change Biology, 25(9), 3136-3150.

Sedmakova, D., Sedmak, R., Bosela, M., Jezik, M., Blazenec, M., Hlasny, T., \& Marusak, R. (2019). Growth-climate responses indicate shifts in the competitive ability of European beech and Norway spruce under recent climate warming in East-Central Europe. Dendrochronologia, 54, 37-48.

Shijatov, S. G., Vaganov, E. A., Kirdjanov, A. V., Kruglov, V. B., Mazepa, V. S., Naurzbaev, M. M., \& Hantemirov, R. M. (2000). Metody dendrohronologii. Chast' 1. Osnovy dendrohronologii. Sbor i poluchenie drevesno-kol'cevoj informacii [Methods of dendrochronology. Part 1. The basics of dendrochronology. Collection and receipt of tree-ring information]. Krasnoyarsk State University, Krasnoyarsk (in Russian).

Shvedov, F. N. (1892). Derevo kak letopis' zasuh [Tree like a drought record]. Meteorological Bulletin, 5, 163-178 (in Russian).

Sitková, Z., Sitko, R., Vejpustková, M., Pajtík, J., \& Srámek, V. (2018). Intra- and interannual variability in diameter increment of Fagus sylvatica L. and Picea abies L. Karst. in relation to weather variables. Central European Forestry Journal, 64, 223-237.

Suvanto, S., Henttonen, H., Nöjd, P., Helama, S., Repo, T., Timonen, M., \& Mäkinen, H. (2017). Connecting potential frost damage events identified from meteorological records to radial growth variation in Norway spruce and Scots pine. Trees, 31(6), 2023-2034.

Svobodova, K., Langbehn, T., Bjorklund, J., Rydval, M., Trotsiuk, V., Morrissey, R. C., Cada, V., Janda, P., Begovic, K., \& Agh-Labusova, J. (2019). Increased sensitivity to drought across successional stages in natural Norway spruce (Picea abies (L.) Karst.) forests of the Calimani Mountains, Romania. Trees - Structure and Function, 33(5), 1345-1359.

Tishin, D. V., \& Chizhikova, N. A. (2018). Dendrohronologija [Dendrochronology] Kazan' University, Kazan' (in Russian)

Tyukavina, O. N., Il'intsev, A. S., \& Ershov, R. A. (2017). The effect of thinning on the radial increment of scotch pine. Bulletin of Higher Educational Institutions. Lesnoi Zhurnal, 4, 3444.

Van de Gevel, S. L., Larson, E. R., \& Grissino-Mayer, H. D. (2017). Separating trends in whitebark pine radial growth related to climate and mountain pine beetle outbreaks in the Northern Rocky Mountains, USA. Forests, 8(6), 195.

Wang, B., Chen, T., Xu, G., Wu, M., Zhang, G., Li, C., \& Wu, G. (2018). Anthropogenic-management could mitigate declines in growth and survival of Qinghai spruce (Picea crassifolia) in the east Qilian Mountains, northeast Tibetan Plateau. Agricultural and Forest Meteorology, 250, 118-126.

Zhang, R., Yuan, Y., Gou, X., Zhang, T., Zou, C., Ji, C., Fan, Z., Qin, L., Shang, H., \& Li, X. (2016). Intra-annual radial growth of Schrenk spruce (Picea schrenkiana Fisch. et Mey) and its response to climate on the northern slopes of the Tianshan Mountains. Dendrochronologia, 40, 36-42. 